\title{
TRIBU - IMÁGENES PARA UNA ANTROPOLOGÍA DE LA POSTERIDAD
}

\author{
MASSIMO COVA ${ }^{1}$
}

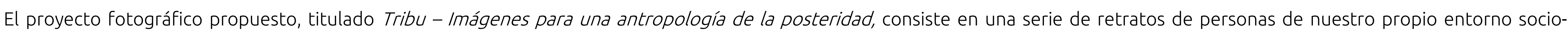

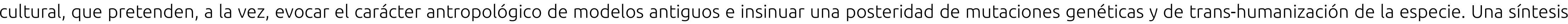
entre la herencia del pasado y las expectativas de un incierto futuro en la construcción presente de nuestra identidad.

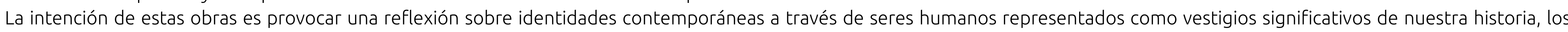

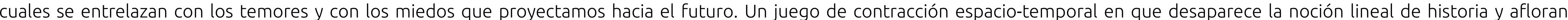

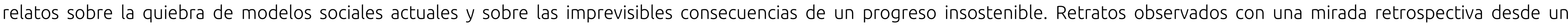
hipotético futuro como espejos de nuestro propio presente en alusión al discurrir no lineal del tiempo de nuestra existencia.

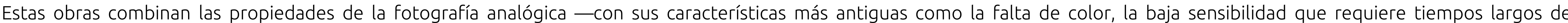

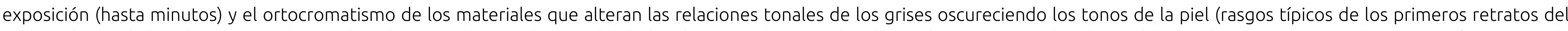

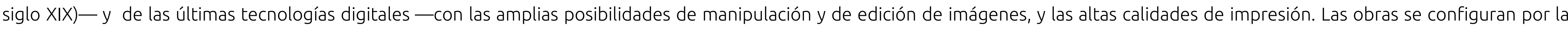
ambigüedad entre el color y el blanco y negro, entre el negativo y el positivo, entre lo pasado y lo futurible como señales de presagio de una siniestra posteridad.

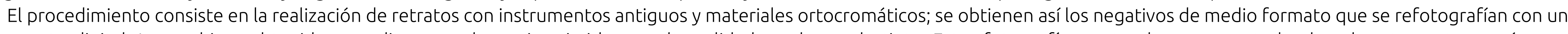

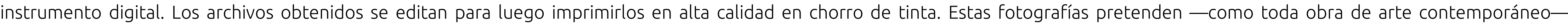
hacernos pensar en aspectos del mundo en que vivimos, sin ofrecer respuestas o explicaciones, sino provocando consideraciones y preguntas. 

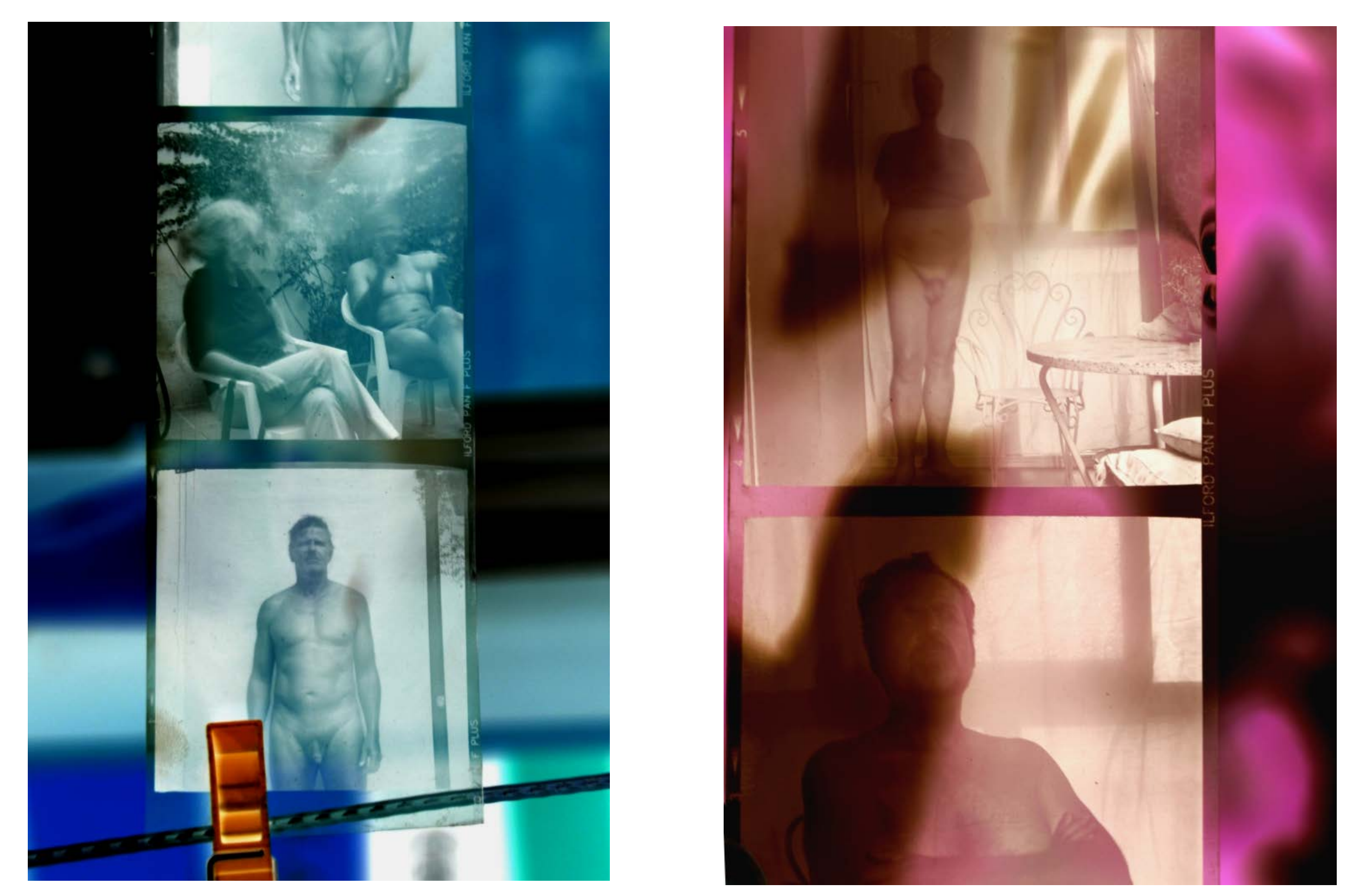


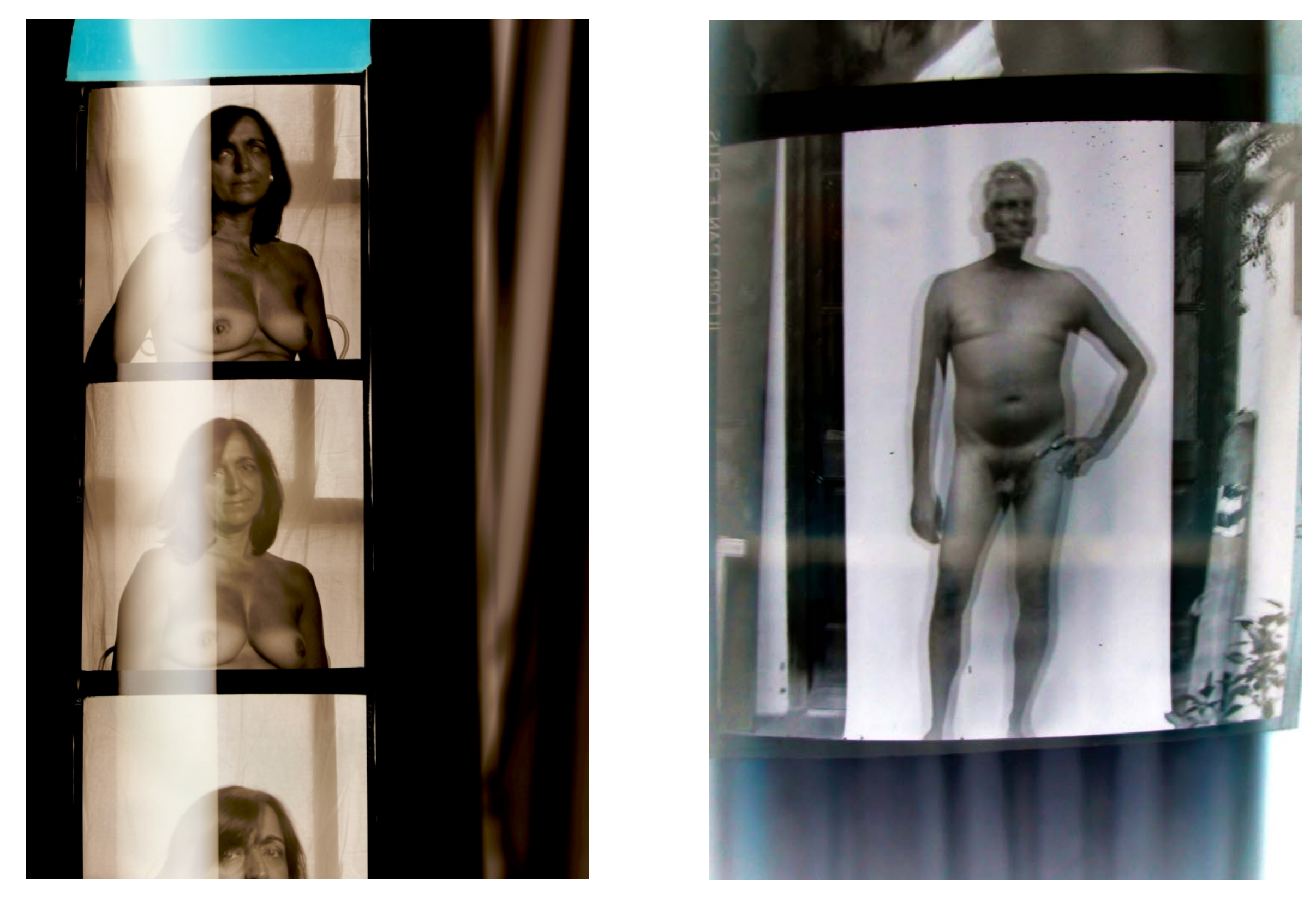



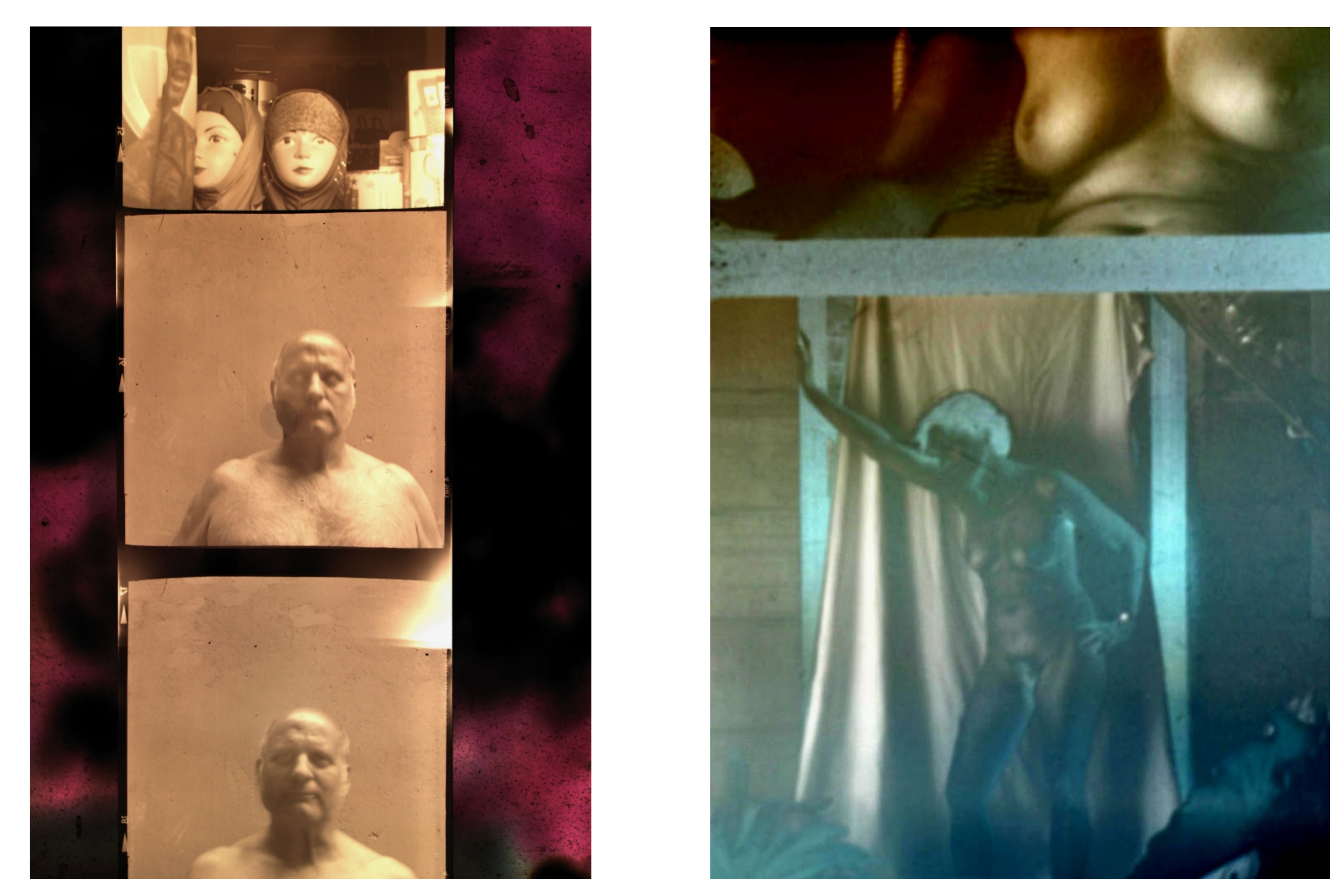


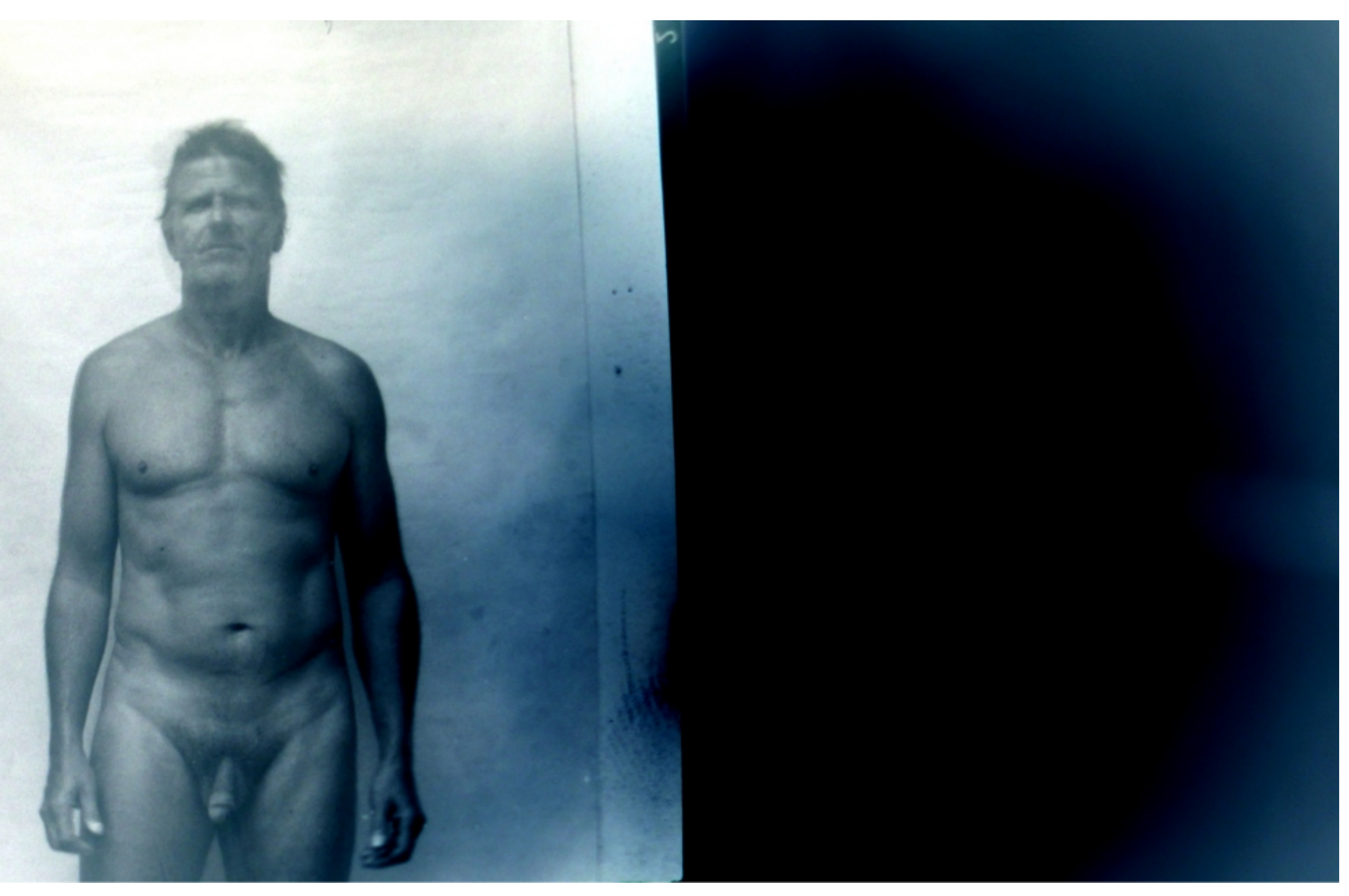


